\title{
FICUS GLANDULIFERA AND ALLIED SPECIES (MORACEAE), INCLUDING A NEW ONE FROM BORNEO AND CELEBES
}

\author{
C.C. BERG \\ Bergen Museum, University of Bergen, Allégate 41, 5007 Bergen, Norway; \\ Nationaal Herbarium Nederland, University Leiden branch, P.O. Box 9514, \\ 2300 RA Leiden, The Netherlands; berg@nhn.leidenuniv.nl
}

\section{SUMMARY}

A revisional study on Ficus glandulifera and allied species was carried out, resulting in emended descriptions of $F$. glandulifera and $F$. lamponga and the description of a new species, F. lumutana.

Key words: Moraceae, Ficus, Malesia, new species.

\section{INTRODUCTION}

The study of the genus Ficus for the Flora of Thailand led to a re-investigation of F. glandulifera and F. lamponga and related species in the Malesian region (see Berg \& Corner 2005: 104). This resulted in emended descriptions of the two species and the discovery of a new species from Borneo and Celebes.

\section{Ficus glandulifera (Wall. ex Miq.) King}

Tree up to $30 \mathrm{~m}$ tall, deciduous. Leafy twigs $2-4 \mathrm{~mm}$ thick, (dark) brown subtomentose or densely (to sparsely) brown(ish) patent- to appressed-puberulous, with pairs of waxy glands at the bases of the petioles; periderm persistent; branches usually dark purplish to blackish with prominent scars of the petioles. Leaves spirally arranged; lamina elliptic to oblong to (sub)obovate or to (sub)ovate (or lanceolate), (4-)6-16(-20) by (2-)3.5-8(-9) cm, chartaceous to subcoriaceous, apex acuminate, base subcordate to cordulate to cuneate, margin entire, dent(icul)ate or faintly repand; upper surface appressed-puberulous to brown subtomentose on the main veins, smooth, lower surface brown subtomentose to puberulous or partly strigillose on the veins; cystoliths absent; lateral veins $5-8(-10)$ pairs, the basal pair, up to $1 / 3-1 / 2$ the length of the lamina, clearly or faintly branched, tertiary venation scalariform; waxy glands in the axils of the basal lateral veins or absent, but a pair of glands mostly present at or below the base of the petiole; petiole $1-10 \mathrm{~cm}$ long, brown subtomentose to \pm densely appressedpuberulous, the epidermis mostly flaking off; stipules $0.5-0.8 \mathrm{~cm}$ long, brown (or yellowish) subtomentose to subsericeous (near the margins often glabrous), caducous. Figs mostly below the leaves on previous season's growth, in pairs; peduncle $0.3-1.3$ cm long; basal bracts 3, 1.5-2.5 mm long, brown appressed-puberulous to strigillose; 
receptacle ellipsoid to subglobose, $0.7-1 \mathrm{~cm}$ diam. when dry, $1.2-1.5 \mathrm{~cm}$ diam. when fresh, sparsely but around the ostiole densely appressed-puberulous to strigillose (or the whole surface densely appressed-puberulous), the surface often veined, sometimes up to $0.5 \mathrm{~cm}$ long stipitate, seed-figs yellow to red at maturity, gall-figs yellowish to orange at maturity and irregularly longitudinally dehiscent, apex convex, ostiole c. 2 mm diam., \pm prominent; internal hairs abundant, yellowish.

Distribution - As indicated in Berg \& Corner 2005: 110.

\section{Ficus lamponga Miq.}

Tree up to $33 \mathrm{~m}$ tall, becoming slightly buttressed, deciduous; milk sap watery. Leafy twigs 2-4 mm thick, densely to sparsely brown(ish) appressed-puberulous to strigillose; periderm persistent; branches dark brown to purplish, scars of the stipules \pm prominent. Leaves spirally arranged; lamina oblong to elliptic to (subobovate) to lanceolate, $8-25$ by $3.5-13 \mathrm{~cm}$, chartaceous, apex acuminate, base truncate to rounded to cuneate, margin entire; upper surface brownish appressed-puberulous on the veins or only on the midrib, smooth, lower surface brown appressed-puberulous to strigillose on the veins; cystoliths absent; lateral veins (8-)10-13(-18) pairs, branched, the basal pair up to $(1 / 8-) 1 / 6-1 / 4(-1 / 3)$ the length of the lamina, branched or unbranched, sometimes also other lateral veins branched or furcate away from the margin, tertiary venation scalariform; waxy glands absent on the lamina, but often a single transversely band-shaped gland at the base of the petiole; petiole $2-7.5 \mathrm{~cm}$ long, brown appressed-puberulous to strigillose or tomentose to hirtellous, the epidermis flaking off; stipules $0.5-1.2 \mathrm{~cm}$ long, brown appressed-puberulous to strigillose, sometimes only on the keel, rarely subglabrous, caducous. Figs below the leaves on previous season's growth, in pairs; peduncle (0.2-)0.5-1 cm; basal bracts 3,2-3 mm long, densely to sparsely appressedpuberulous; receptacle subglobose to ellipsoid, $0.8-1.3 \mathrm{~cm}$ diam. when dry, $1.3-1.6 \mathrm{~cm}$ diam. when fresh, mostly non-stipitate, sometimes up to $0.5 \mathrm{~cm}$ long stipitate, densely to sparsely brownish puberulous to subglabrous, the surface veined, seed-figs orangeochre to red at maturity, gall-figs greenish at maturity and irregularly longitudinally dehiscent, apex convex or \pm protracted, ostiole 2.5-3.5 mm diam., prominent; internal hairs abundant, yellow.

Distribution - NE India, Myanmar, Indochina, Thailand, Andaman Islands; in Malesia: Malay Peninsula, Sumatra.

Notes - 1. In Malesia, this species is confined to the Malay Peninsula and Sumatra, for the greater part by specimens provisionally named $F$. glandulifera var. multinervia by Corner.

2. A form with narrow laminas and relatively short petioles and basal lateral veins, recognized as F. lepidosa var. martabanica King (=F. lamponga Miq. var. martabanica (King) Basu (1994) 447), is found scattered in the range of the species.

3. Material with sparsely hairy, sometimes only ciliolate stipules is found in the northern part of the species range, in the southern part the stipules are mostly densely hairy; the type of $F$. lamponga (a sterile collection with a leafy twig with some leaves from Sumatra) might be an exception as the indumentum on leafy twigs and the lamina is rather sparse. 
Ficus lumutana C.C. Berg, spec. nov. - Fig. 1

Fico lamponga similis, ramulis foliosis subglabris, venis lateralibus paucioribus, stipulis ciliolatis solum differt. - Typus: K. Sidiyasa et al. 3407 (holo WAN; iso BO, K, L), Indonesia, East Kalimantan, Paser District, Gunung Lumut Protection Forest, between Rantau Layung and Mului, off km 64, 600 m, 15 Nov. 2005.

Tree up to $35 \mathrm{~m}$ tall, buttressed, deciduous; milk sap watery (or milky). Leafy twigs 2-4 $\mathrm{mm}$ thick, glabrous or sparsely appressed puberulous; periderm persistent; branches dark brown to purplish, scars of the stipules \pm prominent. Leaves spirally arranged; lamina oblong to elliptic (to subobovate), $5-15$ by $2-5 \mathrm{~cm}$, chartaceous, apex acuminate, base rounded to cuneate, margin entire; upper surface sparsely appressed-puberulous on the midrib, smooth, lower surface sparsely appressed-puberulous on the main veins or only on the midrib; cystoliths absent; lateral veins 7-9 pairs, none branched or furcate away from the margin, the basal pair up to $1 / 10-1 / 6$ the length of the lamina, running close to the margin, unbranched, tertiary venation scalariform; waxy glands absent on the lamina, but a single vague or clear (sub)median circular gland at or below the base of the petiole; petiole 1-4 cm long, (sparsely) appressed-puberulous or subglabrous, the epidermis flaking off; stipules $0.5-1 \mathrm{~cm}$ long, (only) brown ciliolate, caducous. Figs below the leaves on previous season's growth, in pairs or solitary; peduncle $0.5-1.5 \mathrm{~cm}$ long; basal bracts 3, 1-2 mm long, (only) ciliolate; receptacle subglobose, $0.8-1.2 \mathrm{~cm}$ diam. when dry, mostly $0.5 \mathrm{~cm}$ long stipitate, sparsely puberulous to glabrous, veined, seed-figs orange to yellow at maturity, gall-figs greenish (to yellowish) at maturity and irregularly longitudinally dehiscent, apex convex or slightly protracted, ostiole 2-2.5 mm diam., \pm prominent; internal hairs abundant, yellow.

Distribution - Malesia: Borneo (Kalimantan, Sabah, Sarawak), Sulawesi.

Habitat - Primary and secondary forest at altitudes up to c. $1000 \mathrm{~m}$.

Notes - 1. Most of these collections were identified as F. lamponga from which they differ sufficiently to be recognised as representatives of a new species. The main differences are: leafy twigs subglabrous, stipules glabrous outside, only ciliolate, less lateral veins, shorter basal lateral veins, and always stipitate fig receptacles. In most of these features the new species also differs from $F$. glandulifera, of which the figs are often stipitate in Borneo.

2. This species belongs to a group of species (ser. dehiscentes sensu Corner) of which the gall-figs are dehiscent at maturity; however, in none of the studied collections of the new species this feature is manifest, neither is it clear whether this species is deciduous like the other members of the group.

3. The new species can be keyed out in the general key in Berg \& Corner (2005: 75) as follows:

44(new)a. Lamina hairy, at least on the midrib above and beneath; midrib reaching the apex of the lamina; fig receptacle $0.8-1.8 \mathrm{~cm}$ diam. when dry .. 45(new)

44(new)b. Lamina (sub)glabrous; midrib often not reaching the apex; fig receptacle $0.2-0.8 \mathrm{~cm}$ diam. when $\mathrm{dry} \ldots \ldots \ldots \ldots \ldots \ldots \ldots \ldots \ldots \ldots$ (old) 45(new)a. Venation prominent beneath; figs sessile, receptacle $1.5-1.8 \mathrm{~cm}$ diam. when

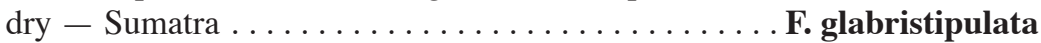

45(new)b. Venation almost flat beneath; figs pedunculate, receptacle $0.8-1.2 \mathrm{~cm}$ diam. when dry - Borneo, Celebes . . . . . . . . . . . . F. lumutana $45($ old $) \rightarrow 46+$ subsequent number changes; 


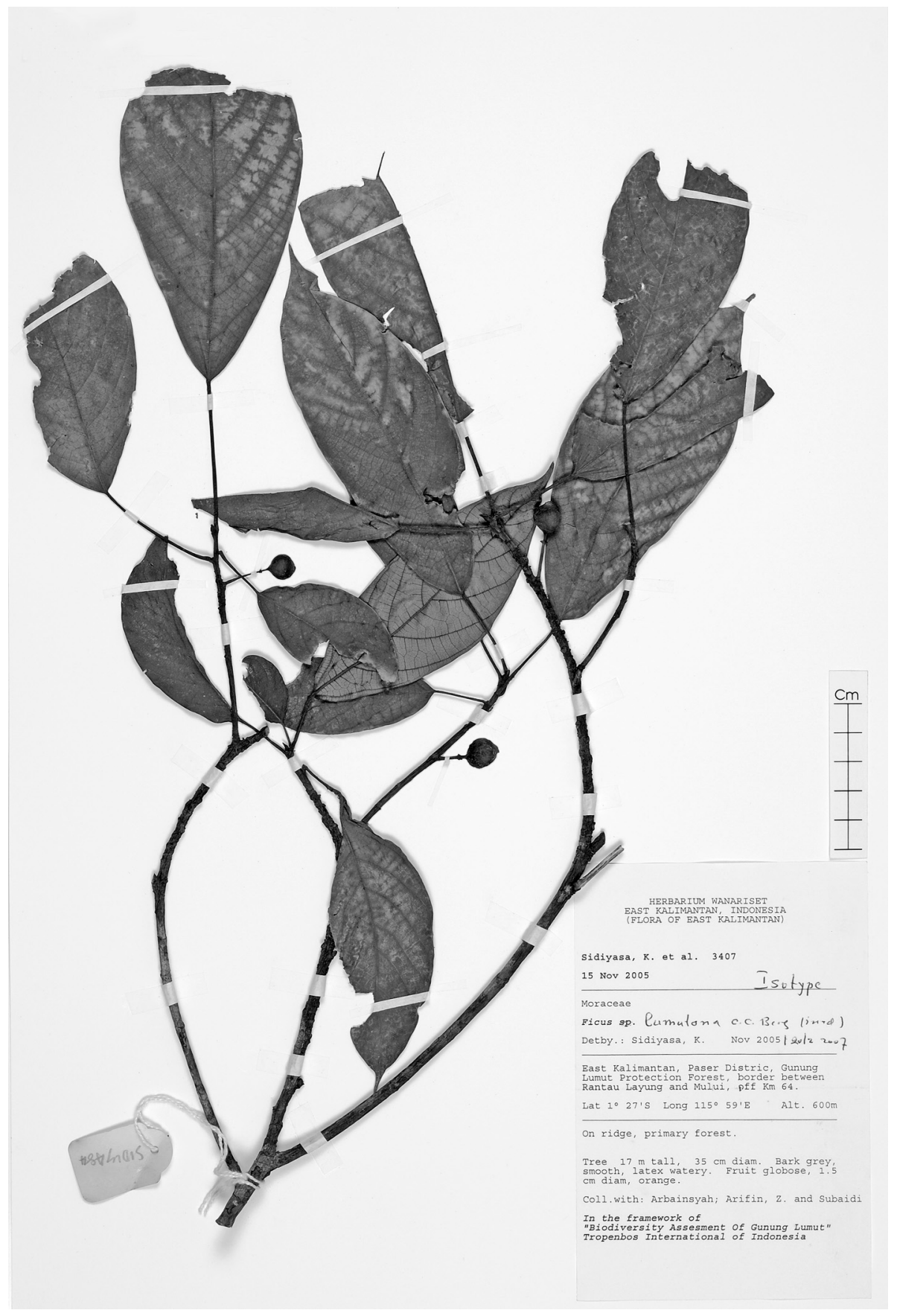

Fig. 1. Ficus lumutana C.C. Berg. Leafy twigs with figs (K. Sidiyasa et al. 3407, L), Indonesia, East Kalimantan, Paser District, Gunung Lumut Protection Forest. 
And in the regional key for Borneo in Berg \& Corner (2005: 83) as follows:

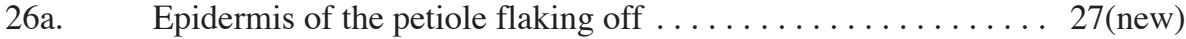

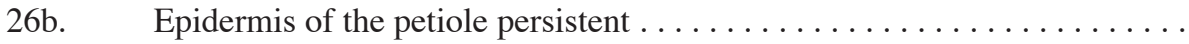
$\ldots \ldots \ldots \ldots \ldots \ldots \ldots \ldots \ldots$ 27 (old) $\rightarrow 28+$ subsequent number changes

27(new)a. Petiole $0.2-1.5 \mathrm{~cm}$ long; waxy glands present on the lamina beneath; fig receptacle $0.2-0.8 \mathrm{~cm}$ diam. when dry . . . . . . . . F. deltoidea

27(new)b. Petiole (1-)1.5-4 cm long; waxy glands absent on the lamina beneath; fig receptacle $0.8-1.2 \mathrm{~cm}$ diam. when dry. . . . . . . . F. lumutana

and in the regional key for Celebes in Berg \& Corner (2005: 87) as follows:

$6($ new)a. Epidermis of the petiole flaking off $\ldots \ldots \ldots \ldots \ldots \ldots \ldots \ldots \ldots \ldots$ (new)

6 (new)b. Epidermis of the petiole persistent $\ldots \ldots \ldots \ldots \ldots \ldots \ldots \ldots \ldots$ $\ldots \ldots \ldots \ldots \ldots \ldots \ldots$ (old) $\rightarrow$. $8+$ subsequent number changes

7(new)a. Petiole $0.2-1.5 \mathrm{~cm}$ long; waxy glands present on the lamina beneath; fig receptacle $0.2-0.8 \mathrm{~cm}$ diam. when dry $\ldots \ldots \ldots \ldots \ldots$ F. deltoidea

7(new)b. Petiole (1-)1.5-4 cm long; waxy glands absent on the lamina beneath; fig receptacle $0.8-1.2 \mathrm{~cm}$ diam. when dry . . . . . . . . . lumutana

Additional specimens examined:

MaLAYSIA. Sabah: Maikin \& Lideh SAN 131050 (E, L), Beluran District, Bidu-Bidu, 1 March 1991; Mikil SAN 31975 (L), Beaufort District, Beaufort Hill, 7 Jan. 1963; Sarawak: Chai et al. S 36729

(L), Gunong Buri, Ulu Simunjan, 180 m, 8 March 1977 (L); Ilias bin Paie S 13336 (L), Lundu District, G. Gading, c. 950 m, 7 April 1961; Ilias bin Paie S 28438 (L), Kapi District, Balang/Balleh ulu Balleh, c. 1000 m, Feb. 1970.

INDONESIA. Kalimantan: Argent \& Saridan 9351 (E, L), road Sangai-(S. Mantaya)-Kab. Korawaringin Timur, km 62, 3 Feb. 1993; Church et al. 2873 (E, L), Serawai, 5 km E of Nanga Jelundung, 120 m, 1 Nov. 1995; Leighton 398 (L), East Kutai Reserve, near Sangata and Mentolo Rivers; Neth. Ind. For. Serv. bb.20737 (L), SE Kalimantan, above Mahakam, D. Parei, 23 Feb. 1936. - Sulawesi: Ned Ind. For. Service Cel./IV-149, Malili, 25 m, 21 March 1934.

\section{ACKNOWLEDGEMENTS}

Some of the data in this study have been acquired during a visit to herbarium E(dinburgh), financed by the European Commission's Research Infrastructure Action via the SYNTHESYS Project. Dr. J.F. Veldkamp (Leiden) translated the diagnosis into Latin.

\section{REFERENCES}

Basu, D. 1994. Ficus lamponga Miq. var martabanica (King) Basu, comb. nov. J. Econ. Taxon. Bot. 18: 447.

Berg, C.C. \& E.J.H. Corner. 2005. Moraceae, Ficus. Flora Malesiana, Ser. I, 17/2. Leiden. 